\title{
Audit Committee and Earnings Management: The Role of Gender
}

\author{
Widya Aulia Sudarman and Widi Hidayat \\ Fakultas Ekonomi dan Bisnis, Universitas Airlangga, Surabaya \\ Email: widyaauliasudarman1995@gmail.com
}

\begin{abstract}
This study has a purpose to investigate the effect of committee audit on earnings management. Using a sampel of companies companies listed in Indonesia Stock Exchange (IDX) 2013-2017. Results of this study shows that gender of audit committee significantly effect earnings management, it explains that female on audit committee are more careful and allow for discretion in terms of financial reporting. The results explain gender theory that women are more risk averse and ethical than men. This research provides new insights for management so that they can consider gender in the selection of committee audit to be appointed by the company with regard to the financial reporting process.
\end{abstract}

Keyword: auditor gender, earnings management.

\section{INTRODUCTION}

Today with globalization triggers technological development in various countries in the world, where countries compete with each other to show their potential in the eyes of the public. This in turn makes the company strive to look perfect and provide positive value for the future. For example, PT. Pertamina Tbk has implemented transparency in the management of the company as well as being the most transparent company in Indonesia (Haryanto, 2017).

It is expected to have a positive impact on the company so that it triggers investment due to increased investor confidence. Transparency and accountability affect economic growth and reduce the risk of conflict (Kompas, 2017), and are a manifestation of good corporate governance so that the performance and investment climate of the company also increases.

On the other hand there are companies that do the opposite, where company management manipulates earnings by increasing profits in their financial statements so that the company's financial statements become biased and the information submitted becomes not transparent. The act of earnings manipulation is referred to as earnings management, which is an act of the manager who chooses accounting policies to achieve a number of specific objectives and the intended accounting policy is the use of accruals in preparing financial statements (Scott, 2011).

For example the case that occurred in 2019 at PT. Garuda Indonesia Tbk, where this began when two Garuda commissioners considered the 2018 financial statements were not in accordance with PSAK number 23. It is known that projects planned to be received in the next fifteen years, are recognized as revenue in 2018 (Kumparan Bisnis, 2019). This caused the Ministry of Finance and the Indonesia Stock Exchange (IDX) to impose sanctions on PT. Garuda Indonesia Tbk, all Garuda directors and Garuda's auditor permission, namely 
KAP Kasner Sirumapea, were frozen because they were considered not to comply with audit standards.

Cases in large companies are known to bring earnings management issues (Abdullah and Ismail, 2016; Gavious et al., 2012) and companies found to be cheating have been known to use earnings management aggressively. Although legal, earnings management practices are unethical because of their influence on the capital market and the company's credibility (Khlif and Achek, 2017; Liu et al., 2014; Panzer and Muller, 2015; Soliman and Ragab, 2013; Zalata et al., 2018).

It is called unethical because management's intention is to mislead stakeholders and will affect company contracts. Research suggests a positive relationship between earnings management the previous year and fraud that occurred in US companies. Thus, companies that previously used earnings management motivated managers to continue commit fraud in the future rather than manage earnings (Ittonen et al., 2013; Soliman and Ragab, 2013).

Research on earnings management has been studied with diverse results, therefore research on earnings management is still relevant to do. As an example of research conducted by (Perols and Lougee, 2011) which states that there is a positive relationship between earnings management in the previous year and in the future. Thus the company that previously used earnings management, motivated management to continue to practice earnings management in the future.

Agency theory states that corporate executives efficiently report accurate financial information to stakeholders or that they opportunistically manipulate reported earnings for personal gain or to mislead some stakeholders about the company's financial performance. This in turn results in agency conflict so that management tends to do things that benefit themselves compared to the interests of stakeholders (Jensen and Meckling, 1976).

Manager's behavior in carrying out earnings management practices can be minimized by applying a mechanism of good corporate governance which is a series of mechanisms used to limit the emergence of information asymmetry problems that can encourage earnings management. In relation to corporate governance, the audit committee has the role of assisting the board of commissioners in providing views on issues relating to accounting and financial policies, overseeing the company's internal and external control functions and preparing financial statements (Amar, 2014; Arun et al., 2015; Dhaliwal et al., 2010; Gavious et al., 2012; Khlif and Achek, 2017; Sultana and Zahn, 2013; Zalata et al., 2018).

Gender perspectives can increase understanding of motives and the level of involvement in accounting manipulation. Claiming from this perspective is that gender has implications for engaging in certain behaviors, gender-based explanations will clarify the socio-cultural context that is the basis of decision making in organizations.

Existing psychological studies, management and financial literature show that there are significant differences in male and female risk preferences and in decision making (Zalata et al., 2018). Furthermore, in the gender literature shows that women have a less aggressive nature than men (Siboni et al., 2016).

Gender and business ethics literature usually shows that women are more ethical than men in attitudes and behavior (Amar, 2014; Gavious et al., 2012; Gull et al., 2018; Saona et al., 2019), where earnings management is generally seen as an ethical problem by managers and accountants. Research conducted by (Saona et al., 2019) states that women tend to avoid risks and have better ethical values. 
Further research by (Gull et al., 2018) gives the same result, that female audit committee directors tend to reduce the level of corporate earnings management, and that becomes more effective if balanced with business expertise in audit committee membership. And the presence of women on the audit committee results in conservative reporting and lower tax aggressiveness (Albring et al., 2014; Khlif and Achek, 2017). Based on literature and previous research on audit committees and their influence on earnings management, where the audit committee acts as a company monitor in relation to financial reporting practices.

The existence of previous studies that provide mixed results, shows that gender differences of the audit committee is a variable that is still relevant to be studied. In this case the gender literature reveals differences in decision making and risk by men and women. Where women tend to avoid risks and have a less aggressive nature.

So that the presence of women on the audit committee is considered to have an effect on earnings management which ultimately makes the focus of this study.Therefore, researchers are motivated to study the relationship between gender of audit committee and its relationship with earnings management.

\section{THEORETICAL REVIEW}

Earnings Management. Earnings management is an act of managers who choose accounting policies to achieve specific objectives and the intended accounting policy is the use of accruals in preparing financial statements (Scott, 2011). The most important types of earnings management are accrual income management (AEM) and real earnings management (REM).

AEM is the manipulation of earnings by managers through estimation and accounting methods, without a direct impact on cash flow, while REM is the manipulation of earnings by managers through operational activities, which have a direct effect on cash flow (Sun et al., 2011).

Accrual accounting increases the ability of earnings to disclose company performance and hence, establish high-quality and sound financial reporting, but (Dechow et al., 1995) observes that in some aspects, the use of accruals will bring new issues, such as earnings management, where managers are mostly can use some of their preferences with regard to accrual recognition.

There is motivation that encourages managers to behave opportunistically in line with the three main hypotheses in positive accounting theory, namely the bonus plan hypothesis, debt covenant hypothesis and political cost hypothesis (Watts and Zimmerman, 1990). In the bonus plan hypothesis it is explained that the company owner promises managers will receive a number of bonuses if the company's performance reaches a certain amount.

This bonus promise is the reason for managers to manage and regulate company profits at a certain level as required in order to receive bonuses. According to the debt covenant hypothesis, it is stated that in the context of a debt agreement, the manager will manage and manage the company's profits so that the company's debt obligations that should be settled in a certain year can be postponed for the following year. According to the political cost hypothesis, it is stated that earnings management is due to government regulations, for example regulations in taxation. 
The size of the tax depends on the size of the company's profits. The greater the company's profits, the greater the tax that will be withdrawn by the government. This condition stimulates managers to manage and regulate company profits so that the amount of tax paid is not too high. In addition, earnings management is also motivated to influence stock performance and tax avoidance, in addition (Scott, 2011) states that earnings management actions are usually carried out through four patterns, namely taking a bath, income minimization, income maximization, and income smoothing.

However, in general, earnings management techniques carried out are divided into three, namely: (1) take advantage of opportunities to make accounting estimates; (2) change the accounting method; and (3) shift the cost or revenue period.

Agency Theory. (Jensen and Meckling, 1976) defines agency relations as a contract in which one party (principal) involves another party (agent) to perform services on their behalf. As part of this, the principal will delegate some decision-making authority to the agent. These agency problems arise because of the impossibility of a perfect contract for every possible action from an agent whose decisions affect his welfare and principal's welfare.

The granting of authority to an agent causes its own problems because the agent will use it to maximize personal utility and can be detrimental to the principal. To reduce agency costs, principals will incur monitoring costs. According to agency theory, monitoring expenditures allow principals to better observe agent actions, monitoring costs including the costs of recruiting board members who will then form subcommittees such as audit committees.

To reduce agency problems, the audit committee has an important role to oversee, monitor and provide opinions on the performance of company management in implementing the company's internal control system and is responsible for resolving issues of interest and earnings management within the company (Al-absy et al., 2018; Gull et al., 2018). In other words, agency theory considers the formation of an audit committee as a tool to minimize agency costs and enhance internal control and introduce it as an effective monitoring tool to strengthen agency relationships (Salehi et al., 2018).

Regarding the presence of women on board related to gender diversity, (Salehi et al., 2018) stated that the presence of women's audit committees is likely to contribute to increased monitoring because they tend to avoid risks, so their presence is considered effective in reducing agency costs. In addition, gender diversity facilitates effective monitoring by expanding expertise, experience, interests, perspectives and creativity (Ararat et al., 2012; Hoever et al., 2012).

Hypothesis. Agency theory arises because of differences in interests between agents and principals, where agents are company management and principals are stakeholders. In this case the agent is given the authority to carry out the company's operational activities. So the agent has more information than the principal (Jensen and Meckling, 1976).

This information will be used to maximize the personal utility of the agent and can mislead users of financial statements. This eventually led to agency conflict. If not handled immediately, the conflict will lead to earnings management (Kyaw et al., 2015).

To reduce earnings management practices within the company, companies are required to have good corporate governance (Albring et al., 2014; Kyaw et al., 2015). In 
addition the principal will incur monitoring costs due to agency costs. This monitoring fee is a form of corporate governance, which includes the cost of recruiting board members who will then form subcommittees such as an audit committee.

The role of the audit committee is to monitor and provide opinions on the performance of the company's management in implementing the company's internal control system and is responsible for resolving issues of interest and earnings management within the company (Al-absy et al., 2018). It is understood that agency theory uses the formation of audit committees as a tool to minimize agency costs and enhance effective monitoring activities to strengthen agency relationships (Ararat et al., 2012; Nelson and Devi, 2013; Salehi et al., 2018).

Gender literature states the role of women in decision making, the results of the study state that women have a risk averse nature and tend to be less aggressive and have better ethical values and obey the rules (Al-Dhamari and Chandren, 2018; Gavious et al., 2012; Ho et al., 2015; Saona et al., 2019). Previous research has explored gender diversity in relation to earnings management and resulted in significant relationships between female directors and earnings management (Arun et al., 2015; Gavious et al., 2012; Gull et al., 2018; Kyaw et al., 2015; Zalata et al., 2018).

Further research conducted by (Gull et al., 2018) states that women audit committee leaders mitigate earnings management because of their status within the company and the presence of women on the audit committee results in conservative reporting and lower tax aggressiveness (Albring et al., 2014; Khlif and Achek, 2017). Based on previous literature and research, it is expected that having a female audit committee chairman can mitigate corporate earnings management practices.

H1: Gender audit committee mitigates earnings management.

\section{METHODOLOGY}

Based on the hypothesis in this study, this type of research is explanatory research that aims to determine the causal relationship between the variables that influence the hypothesis (Sugiyono, 2012).The approach in research is a quantitative approach which is a method used to examine a particular population or sample that aims to test a predetermined hypothesis. This study aims to analyze the effect of audit committee diversity on earnings management in manufacturing companies listed on the Indonesia Stock Exchange in the 2013-2017 period.

The independent variable in this study is the gender included in the size of the category. Therefore the variable must use a dummy variable. In this study divided into two categories, namely men $=0$ and women $=1$. The dependent variable of research is earnings management which is believed to be the manager's actions to achieve certain goals by using an accounting policy in financial reporting. The accounting policy used is the use of accruals.

The dependent variable in this study is earnings management. Dechow et al (1995) tested a different approach in estimating nondiscretionary accruals. They found that the modified jones model (Jones, 1991) gave better results, especially in the detection of earnings management. We use modified jones model for testing earnings management for dependent variable. 
The control variable in this research is leverage, where it is the amount of debt used to buy company assets. Companies with a high degree of leverage usually have greater incentives to increase revenue, this is to avoid debt restrictions (Abdullah and Ismail, 2016; Badolato et al., 2014; Gull et al., 2018). Therefore, leverage affects the company's earnings management. In this study leverage is measured using the ratio of total liabilities divided by total equity

Size is the size of the company is a classification value of the size of a company based on total assets, stock market value, log size, and others. In relation to earnings management, companies with relatively large size have high pressure to produce accurate financial reporting. Therefore, company size influences earnings management. The total amount of assets of a company shows the size of the company. In this study, company size is measured as the natural logarithm of the company's total assets (Nelson and Devi, 2013). Size control variable is measured using the log of total assets of the company.

The ROA variable is a measure of a company's effectiveness by utilizing its assets to generate profits. In addition, ROA is one proxy that illustrates the company's financial condition, it is expected that companies with higher financial performance tend to manage income downwards. So that ROA affects earnings management. In this study ROA is measured by the formula net income divided by total assets (Abdullah and Ismail, 2016).

Loss can be interpreted as expenses or expenses that are greater than the income received, is one proxy that illustrates the company's financial condition. It can be said that the problematic companies have higher motivation to engage in earnings management (Arun et al., 2015; Gavious et al., 2012; Ittonen et al., 2013; Srinidhi et al., 2011). It is an indicator variable that is set to 1 if net income is negative and 0 if net income is positive.

The type of data used in the study is secondary data, obtained from existing sources in the form of financial reports and annual reports of manufacturing companies in 20132017. The source of the data was obtained from the official site of the Indonesia Stock Exchange (IDX), namely www.idx.co.id. The sample of this research are all companies in the Indonesia Stock Exchange (IDX) for the period 2013-2017. Based on a purposive sampling technique, as many as 1345 companies were selected to become a research sample with the criteria in the table below.

Table 1. Determination of Research Samples

\begin{tabular}{llc}
\hline No & \multicolumn{1}{c}{ Criteria } & Total \\
\hline 1 & $\begin{array}{l}\text { Companies listing on the Indonesia Stock Exchange } \\
\text { in the period 2013-2017 }\end{array}$ & 2250 perusahaan \\
2 & Financial Company & (400 perusahaan) \\
3 & Companies with incomplete financial statements & (285 perusahaan) \\
4 & Companies that use USD in financial reporting & (220 perusahaan) \\
\hline & Jumlah sampel perusahaan & 1345 \\
\hline
\end{tabular}

Source: (Resource data, 2019)

The data collection method used is documentation technique. The first data collection process, researchers looked for sample company data from the Indonesia Stock Exchange website, namely at www.idx.co.id and the Indonesia Capital Market Directory (ICMD) 
2013-2017. Data documented in the financial statements are gender audit committee, accounts receivable, total assets, fixed assets, sales, net income, OCF, loss, ROA, DAR, size. Linear regression is a statistical test by looking at the statistical results of the test results with a testing tool using STATA.

Multiple linear regression analysis techniques are used in this study because they can explain the relationship and the effect of independent variables on the dependent variable. So that in research, multiple linear regression analysis examines the relationship between the dependent variable, earnings management and the independent variable, namely the audit committee's gender, and control variables, namely leverage, ROA, loss and size. The following linear regression equation in this study.

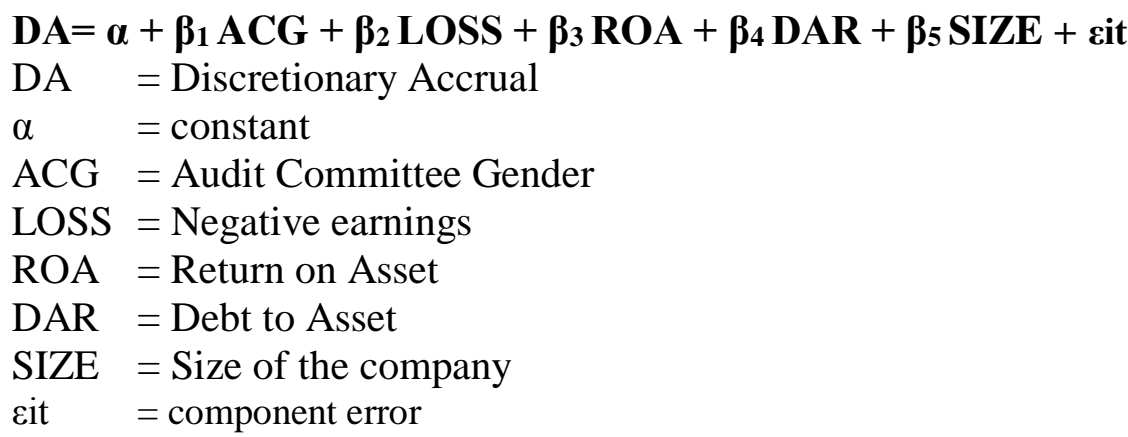

\section{THE RESULTS OF STATISTICAL TESTS}

Based on descriptive statistical tables it can be seen that the dependent variable, earnings management in this study has an average value of 0.015376 , this range is quite high on this variable, seen from the difference between the maximum 1,112 and -2,684 minimum. The independent variable in the study is that the gender audit committee has a distribution of 387 or $29.8 \%$ of companies led by female audit committees and the remaining 958 companies or $71.2 \%$ are led by male audit committees.

Furthermore, the ROA control variable has an average of 0.0237481 with a minimum value of -17.67 and a maximum of 3.3. The second control variable, DAR, has an average value of 0.54 with a minimum value of -1.458 and a maximum value of 1,683 . The third control variable, SIZE, has an average value of 2,833 with a minimum value of -1.458 and a maximum value of 3,332. The last control variable is LOSS, as many as 294 companies have positive net income and the remaining 1051 companies have positive net income. 
Table 2. Statistic Descriptive

\begin{tabular}{|c|c|c|c|c|c|}
\hline Variable & Obs & Mean & Std. Dev. & Min & Max \\
\hline EM & 1,345 & 015376 & .4423742 & -2.684 .265 & 1.112 .111 \\
\hline ROA & 1,345 & .0237481 & .6313825 & -17.67 & 3.3 \\
\hline DAR & 1,345 & .5424522 & .8228406 & -1.458 .727 & 1.683 .488 \\
\hline SIZE & 1,345 & 2.833 .591 & 1.860 .144 & 1.858 .927 & 3.332 .018 \\
\hline \multicolumn{6}{|c|}{$\begin{array}{l}\text { Dummy } \\
\text { Variabel }\end{array}$} \\
\hline Variable & \%Score1 & & \%Score2 & \multicolumn{2}{|c|}{ Total\% } \\
\hline ACG & (387) $28.8 \%$ & & (958) $71.2 \%$ & \multicolumn{2}{|c|}{ 100\% (1345) } \\
\hline LOSS & (294) $21.9 \%$ & & (1051) $78.1 \%$ & \multicolumn{2}{|c|}{ (1345) 100\% } \\
\hline
\end{tabular}

Source: (Research data, 2019)

Table 3 presents Pearson correlation used to determine the strength of the relationship between variables. In the table it can be seen that the gender audit committee has a negative correlation with a significance level of $5 \%$ on earnings management. This explains that the company with the chairman of the female audit committee has a significant influence to mitigate earnings management. Furthermore LOSS has a significant effect with a negative correlation on earnings management, with a significance level of $10 \%$. ROA has a significant effect with a negative correlation on earnings management, a significance level of $1 \%$.

Table 3. Pearson Correlation Result

\begin{tabular}{lccccc}
\hline & EM & ACG & LOSS & ROA & DAR \\
\hline EM & 1.000 & & & \\
ACG & & & & \\
& $-0.059^{* * *}$ & 1.000 & & & \\
LOSS & $(0.030)$ & & & & \\
& $-0.080^{* * *}$ & 0.021 & 1.000 & 1.000 & \\
ROA & $(0.003)$ & $(0.431)$ & & & \\
& $-0.230^{* * *}$ & 0.019 & $-0.212^{* * *}$ & & \\
DAR & $(0.000)$ & $(0.496)$ & $(0.000)$ & $-0.264^{* * *}$ & \\
& 0.008 & $-0.058^{* *}$ & $0.159^{* * *}$ & $(0.000)$ & \\
SIZE & $(0.780)$ & $(0.034)$ & $(0.000)$ & $0.105^{* * *}$ & $-0.104^{* * *}$ \\
& -0.042 & $0.061^{* *}$ & $-0.109^{* * * *}$ & $(0.000)$ & $(0.000)$ \\
\hline
\end{tabular}

$p$-values in parentheses ${ }^{*} p<0.1,{ }^{* *} p<0.05,{ }^{* * *} p<0.01$

Source: (Resource data, 2019) 
The hypothesis in the study was tested by multiple linear regression tests. In this study, the model used is feasible to do a multiple linear regression test because it has passed the classic assumption test. Furthermore, the F test results show a significance value of 0.000 , it can be concluded that the gender and audit committee control simultaneously have a significant effect on earnings management.

Table 4 shows that the hypothesis in this study which states that the gender audit committee mitigates the company's earnings management is accepted. With a significance level of 5\% (0.047 <0.05), so H1 is accepted. Explanation of the results in this study is the gender audit committee has a significant influence on earnings management, so it can be concluded that women tend to be able to mitigate corporate earnings management.

The results in the study are in accordance with gender literature which states that women are more risk averse and less aggressive, and have better ethical values (Amar, 2014; Gavious et al., 2012; Gull et al., 2018; Saona et al., 2019). Given the differences in risk preferences and decision making, the presence of a female director on the audit committee is able to limit earnings management practices.

Tabel 4. Statictical Test Results

\begin{tabular}{lcccc}
\hline Variable & \multicolumn{5}{c}{ Earnings Management (EM) } \\
\hline \multirow{2}{*}{ ACG } & Coef. & Std. Err. & t & P>t \\
\cline { 2 - 5 } LOSS & -.0513323 & .0257666 & -1.99 & $0.047^{* *}$ \\
ROA & -.1397975 & .0290589 & -4.81 & $0.000^{* * *}$ \\
DAR & -.1864585 & .0194417 & -9.59 & $0.000^{* * *}$ \\
SIZE & -.0257901 & .0147935 & -1.74 & $0.082^{*}$ \\
Cons & -.0070817 & .0063352 & -1.12 & 0.264 \\
\hline F & .279788 & .1809163 & 1.55 & 0.122 \\
$\mathbf{R}^{2}$ & 0.0000 & & \\
$\mathbf{N}$ & 0.0756 & & \\
& 1345 & & \\
Years Dummy & Included & \\
\hline$p$-values in parentheses ${ }^{*} p<0.1,{ }^{* *} p<0.05,{ }^{* * *} p<0.01$ \\
Source: (Resource data 2019$)$
\end{tabular}

Source: (Resource data, 2019)

Table 5 is the results of robustness tests. Research with regression testing usually finds things that are violated in testing classic assumptions. Therefore, robustness tests are carried out to reduce bias results in research and it is important to analyze data that might be affected by outliers and minimize the influence of outliers on the model so that it produces the best model. The results of the study are also strong where there is almost no difference with the OLS panel data regression model. 
Table 5. Robust Regression Results

\begin{tabular}{lcccc}
\hline Variabel & \multicolumn{4}{c}{ Earning Management (EM) } \\
\cline { 2 - 5 } & Coef. & $\begin{array}{c}\text { Robust } \\
\text { Std. Err. }\end{array}$ & $\mathbf{t}$ & P>t \\
\cline { 2 - 5 } ACG & -.0513323 & .0191316 & -2.68 & $0.007^{* * *}$ \\
LOSS & -.1397975 & .0304959 & -4.58 & $0.000^{* * *}$ \\
ROA & -.1864585 & .1174057 & -1.59 & 0.112 \\
DAR & -.0257901 & .0436213 & -0.59 & 0.554 \\
_Cons & -.0070817 & .0061588 & -1.15 & 0.250 \\
\hline F & .279788 & .1683077 & 1.66 & 0.097 \\
$\mathbf{R}^{2}$ & 0.0000 & & \\
\hline Years Dummy & 0.0756 & & \\
\hline$p$-values in parentheses ${ }^{*} p<0.1,{ }^{* *} p<0.05,{ }^{* * *} p<0.01$ \\
Source: (Resource data, 2019$)$
\end{tabular}

\section{DISCUSSION}

As a result of the separation of contracts between agents and principals where the agent has the authority to carry out company activities. This in turn gives rise to asymmetric information, where agents have more information than principals which agents will ultimately use to maximize personal utility rather than corporate interests. So that if not immediately addressed, it will lead to earnings management practices in the company.

Earnings management is the act of manipulating earnings performed by management to achieve certain goals and is considered unethical because it can mislead users of financial statements in decision making. This conflict can be minimized by monitoring expenses where the audit committee is one of these manifestations.

The audit committee as a manifestation of corporate governance has the role of assisting the board of commissioners in providing views on issues relating to accounting and financial policies, overseeing the internal and external control functions of the company and preparing financial statements (Arun et al., 2015; Bédard and Gendron, 2011; Yang et al., 2018; Zalata et al., 2018).

The role of the audit committee is to monitor and provide opinions on the performance of the company's management in implementing the company's internal control system and is responsible for resolving issues of interest and earnings management within the company (Al-absy et al., 2018). It is understood that agency theory uses the formation of audit committees as a tool to minimize agency costs and enhance effective monitoring activities to strengthen agency relationships (Salehi et al., 2018).

Gender literature states the role of women in decision making, the results of the study state that women have a risk averse nature and tend to be less aggressive and have better ethical values and comply with the rules (Gavious et al., 2012; Saona et al., 2019). Therefore this study focuses on gender in the audit committee on its relationship with earnings 
management, based on previous research, the hypothesis of this study is that the audit committee's gender affects earnings management.

The results of the statistical test show that the hypothesis of the study was accepted (H1 accepted). Therefore this study provides empirical evidence that gender in the audit committee has an impact on earnings management. The results of this study are consistent with research conducted by (Arun et al., 2015), (Gavious et al., 2012), (Gull et al., 2018), (Kyaw et al., 2015) and (Zalata et al., 2018).

From the results of research conducted and previous studies can be seen that the presence of women on the audit committee stated that women on the audit committee have a significant effect on earnings management with a negative direction. This proves that the presence of women on the audit committee is able to limit earnings management practices, because women tend to avoid risks and have better ethics.

The gender literature states that women tend to avoid risk and are not aggressive and have better ethical values than their male counterparts(Gavious et al., 2012; Saona et al., 2019). The results of the study provide empirical evidence that the gender audit committee mitigates earnings management, and is useful for the development of gender literature in corporate decision making, where stakeholders can consider the presence of women on the audit committee due to their influence on earnings management practices.

\section{CONCLUSION}

This study examines the effect of gender in the audit committee on earnings management. The population used in this study are all companies listed on the Indonesia Stock Exchange for the period 2013-2017. The quantitative method used in this study and the test tool used is STATA with data analysis techniques using multiple linear regression analysis.

The results of the statistical test support the hypothesis proposed in this study, where the gender audit committee influences earnings management. Based on agency theory which states that differences in interests between principals and agents can be minimized by the existence of corporate governance, where the audit committee is a form of good governance. In addition, there is a gender literature which states that men and women have differences in risk preferences and women are considered more ethical than male counterparts. Therefore, the presence of women on the audit committee has an impact on corporate earnings management practices. The results in the study provide empirical evidence that the gender audit committee mitigates earnings management and provides additional knowledge in the gender literature. Limitation in this study is the number of female audit committee chairpersons in the company is 387 or around $28.8 \%$ while the male audit committee chairperson is 958 or around $71.2 \%$, this may affect the research results.

\section{REFERENCE}

Abdullah, S. N., and Ismail, K. N. I. K. (2016). Women Directors, Family Ownership and Earnings Management in Malaysia. Asian Review of Accounting, 24(4), 525-550. https://doi.org/10.1108/ARA-07-2015-0067.

Al-absy, M. S. M., Ismail, K. N. I. K., and Chandren, S. (2018). Accounting Expertise in 
the Audit Committee and Earnings management. Business and Economic Horizons. https://doi.org/10.15208/beh.2018.33.

Al-Dhamari, R. A. A., and Chandren, S. (2018). Audit Partners Gender, Auditor Quality and Clients Value Relevance. Global Business Review, 19(4), 952-967. https://doi.org/10.1177/0972150917697747.

Albring, S., Robinson, D., and Robinson, M. (2014). Audit committee financial expertise, corporate governance, and the voluntary switch from auditor-provided to non-auditorprovided tax services. Advances in Accounting, 30, 81-94.

Amar, A. Ben. (2014). The Effect of Audit Committee Financial Experts on Earnings Management. 6(2), 156-166.

Ararat, M., Aksu, M. H., and Cetin, A. T. (2012). The Impact of Board Diversity on Boards' Monitoring Intensity and Firm Performance: Evidence from the Istanbul Stock Exchange. SSRN Electronic Journal, 90(216). https://doi.org/10.2139/ssrn.1572283.

Arun, T. G., Almahrog, Y. E., and Aribi, Z. (2015). Female Directors and Earnings Management: Evidence from UK Companies. International Review of Financial Analysis, 39, 137-146. https://doi.org/10.1016/j.irfa.2015.03.002.

Badolato, P. G., Donelson, D. C., and Ege, M. (2014). Audit Committee Financial Expertise and Earnings Management: The Role of Status. Journal of Accounting and Economics, 58(2-3), 208-230. https://doi.org/10.1016/j.jacceco.2014.08.006.

Bédard, J., \& Gendron, Y. (2011). Strengthening the Financial Reporting System: Can Audit Committees Deliver? SSRN Electronic Journal, 6(418), 1-66. https://doi.org/10.2139/ssrn. 1438150

Dechow, P. M. ., R.G., S., and A.P., S. (1995). Detecting Earnings Management. The Accounting Review, 70(2), 193-225.

Dhaliwal, D., Naiker, V., and Navissi, F. (2010). The Association Between Accruals Quality and the Characteristics of Accounting Experts and Mix of Expertise in Audit Committees. Contemporary Accounting Research, 27(3), 787-827. https://doi.org/. https://doi.org/10.1111/j.1911-3846.2010.01027.x.

Gavious, I., Segev, E., and Yosef, R. (2012). Female Directors and Earnings Management in High-Technology Firms. Pacific Accounting Review, 24(1), 4-32. https://doi.org/10.1108/01140581211221533.

Gull, A. A., Nekhili, M., Nagati, H., and Chtioui, T. (2018). Beyond Gender Diversity: How Specific Attributes of Female Directors Affect Earnings Management. British Accounting Review, 50(3), 255-274. https://doi.org/10.1016/j.bar.2017.09.001.

Haryanto, S. A. (2017). TII Sebut Pertamina Korporasi Paling Transparan di RI. Retrieved January 11, 2020, from https://www.cnnindonesia.com/ekonomi/2017120618582292-260634/tii-sebut-pertamina-korporasi-paling-transparan-di-ri.

Ho, S. M., Li, A., Tam, K., and Zhang, F. (2015). CEO Gender, Ethical Leadership, and Accounting Conservatism. Journal of Business Ethics, 127(2), 351-270. https://doi.org/https://doi.org/ 10.1007/s10551-013-2044-0.

Hoever, I. J., Van Knippenberg, D., Van Ginkel, W. P., and Barkema, H. G. (2012). Fostering team creativity: perspective taking as key to unlocking diversity's potential. Journal of Applied Psychology, 97(5), 982. https://doi.org/https://doi.org/ 10.1037/a0029159.

Ittonen, K., Peni, E., and Vahamaa, S. (2013). Female Auditors and Accruals Quality. American 
https://doi.org/https://doi.org/10.2308/acch-50400.

Jensen, M., and Meckling, W. (1976). Theory of the Firm: Managerial Behavior, Agency Costs and Ownership Structure. Journal of Financial Economics, 3(4), 305-360. https://doi.org/https://doi.org/10.1016/0304-405X(76)90026-X.

Jones, J. (1991). Earnings management during import relief investigations. Journal of Accounting Research, 29(2), 193-228.

Khlif, H., and Achek, I. (2017). Gender in Accounting Research: a Review. Managerial Auditing Journal, 32(6), 627-655. https://doi.org/10.1108/MAJ-02-2016-1319.

Kompas. (2017). Penerapan Transparansi Bisnis Sebagai Kunci Tata Kelola Perusahaan. Retrieved November 29, 2019, from https://biz.kompas.com/read/2017/12/18/090414528/penerapan-transparansi-bisnissebagai-kunci-tata-kelola-perusahaan.

Kumparan Bisnis. (2019). Fakta-Fakta Skandal Laporan Keuangan Garuda. Retrieved November 13, 2019, from https://kumparan.com/kumparanbisnis/fakta-faktaskandal-laporan-keuangan-garuda-1rMwNVMNWKZ.

Kyaw, K., Olugbode, M., and Petracci, B. (2015). Does Gender Diverse Board Mean Less Earnings Management? Finance Research Letters, 14, 135-141. https://doi.org/10.1016/j.frl.2015.05.006.

Liu, Y., Wei, Z., and Xie, F. (2014). CFO Gender and Earnings Management : Evidence from China. https://doi.org/10.1007/s11156-014-0490-0.

Nelson, S. P., and Devi, S. (2013). Audit Committee Experts and Earnings Quality. Corporate Governance: The International Journal of Business in Society, 13(4), 335351. https://doi.org/10.1108/CG-02-2011-0009.

Panzer, L., and Muller, S. (2015). Earnings \{Quality\} and \{Gender\} \{Diversity\} on \{German\} \{Supervisory\} \{Boards\}: \{An\} \{Empirical\} \{Analysis\}. Problems and Perspectives in Management, 13(4), 9-18. https://doi.org/http://businessperspectives.org/component/option,com_journals/task, allissues/id,3/Itemid,74/.

Perols, J., and Lougee, B. (2011). The Relation Between Earnings Management and Financial Statement Fraud. Advances In Accounting, 27(1), 29-53. https://doi.org/https://doi.org/10.1016/j.adiac.2010.10.004.

Salehi, M., Tahervafaei, M., and Tarighi, H. (2018). The effect of characteristics of audit committee and board on corporate profitability in Iran. . . Journal of Economic and Administrative Sciences, 34(1), 71-88. https://doi.org/https://doi.org/10.1108/JEAS04-2017-0017.

Saona, P., Muro, L., San Martín, P., and Baier-Fuentes, H. (2019). Board of Director's Gender Diversity and its Impact on Earnings Management: An Empirical Analysis for Select European Firms. Technological and Economic Development of Economy, 25(4), 634-663. https://doi.org/10.3846/tede.2019.9381.

Scott, W. R. (2011). Financial Accounting Theory (Sixth Edit). Cana: Person Prentice Hall.

Siboni, B., Sangiorgi, D., Farneti, F., and de Villiers, C. (2016). Gender Accounting: Insights, Gaps and an Agenda for Future Research. Meditari Accountancy Research, 24(2), 156-168. https://doi.org/https://doi.org/ 10.1108/MEDAR-04-2016-0054.

Soliman, M., and Ragab, A. A. (2013). Audit Committee Effectiveness, Audit Quality and Earnings Management: An Empirical Study of the Listed Companies in Egypt. SSRN Electronic Journal, 1-29. https://doi.org/10.2139/ssrn.2315355. 
Srinidhi, B., Gul, F., and Tsui, J. (2011). Female Directors and Earnings Quality. Contemporary Accounting Research, 28(5), 1610-1644. https://doi.org/https://doi.org/10.1111/j.1911-3846.2011.01071.x.

Sugiyono. (2012). Metode Penelitian Bisnis (16th ed.). Bandung: Alfabeta.

Sultana, N., and Zahn, J. W. M. Van Der. (2013). Earnings Conservatism and Audit Committee Financial Expertise. Accounting and Finance, (March 2013).

Sun, J., Liu, G., and Lan, G. (2011). Does Female Directorship on Independent Audit Committees Constrain Earnings Management? Journal of Business Ethics, 99(3), 369-382. https://doi.org/10.1007/s10551-010-0657-0.

Watts, R. L., and Zimmerman, J. L. (1990). Positive Accounting Theory: A Ten Year Perspective. The Accounting Review, 65(1), 131-158.

Yang, S., Liu, Y., and Mai, Q. (2018). Is the Quality of Female Auditors Really Better? Evidence Based on The Chinese A-share Market. China Journal of Accounting Research, 11(4), 325-350. https://doi.org/10.1016/j.cjar.2018.07.004.

Zalata, A. M., Tauringana, V., and Tingbani, I. (2018). Audit Committee Financial Expertise, Gender, and Earnings Management: Does Gender of the Financial Expert Matter? International Review of Financial Analysis, 55(March 2017), 170-183. https://doi.org/10.1016/j.irfa.2017.11.002. 